\title{
Lysozyme Aptamer-Functionalized Magnetic Nanoparticles for the Purification of Lysozyme from Chicken Egg White
}

\author{
Ruiping Luo, Xinrui Zhou, Yan Chen, Sicheng Tuo, Fulin Jiang, Xiaodi Niu, Fengguang Pan * and \\ Hongsu Wang * (D) \\ College of Food Science and Engineering, Jilin University, Changchun 130062, China; \\ luorp16@mails.jlu.edu.cn (R.L.); zhouxr14@mails.jlu.edu.cn (X.Z.); chen_y@jlu.edu.cn (Y.C.); \\ tuosc9916@mails.jlu.edu.cn (S.T.); jiangf19916@mails.jlu.edu.cn (F.J.); niuxd@jlu.edu.cn (X.N.) \\ * Correspondence: panfg@jlu.edu.cn (F.P.); wanghs@jlu.edu.cn (H.W.); Tel./Fax: +86-431-8783-6376 (H.W.)
}

Received: 8 January 2019; Accepted: 9 February 2019; Published: 12 February 2019

check for updates

\begin{abstract}
Lysozyme is in high demand due to its many favorable characteristics such as being naturally occurring, non-toxic, and easy to digest and absorb. Recently, superparamagnetic nanoparticles with strong magnetic responsiveness have attracted significant interest for enzyme purification. The aptamer of the enzyme can be chemically synthesized rapidly at a large scale using simple and low-cost preparation methods. Therefore, $\mathrm{Fe}_{3} \mathrm{O}_{4}$ nanoparticles $\left(\mathrm{Fe}_{3} \mathrm{O}_{4} \mathrm{NPs}\right)$ were prepared by chemical co-precipitation and were then functionalized with amino groups to produce $\mathrm{NH}_{2}-\mathrm{Fe}_{3} \mathrm{O}_{4}$ NPs. The specific reaction of aldehyde and amino groups was used to attach lysozyme aptamers with specific sequences to $\mathrm{NH}_{2}-\mathrm{Fe}_{3} \mathrm{O}_{4} \mathrm{NPs}$ to produce Apt- $\mathrm{NH}_{2}-\mathrm{Fe}_{3} \mathrm{O}_{4} \mathrm{NPs}$. The synthesized materials were characterized using transmission electron microscopy (TEM), X-ray diffraction (XRD), Fourier transform infrared spectroscopy (FTIR), hysteresis loop analysis, and thermogravimetric analysis (TGA). The optimal experimental conditions for adsorption of lysozyme were investigated. The effects of initial lysozyme concentration, adsorption time, $\mathrm{pH}$, reaction temperature, and ionic strength were determined. The maximum adsorption capacity and relevant activity of Apt- $\mathrm{NH}_{2}-\mathrm{Fe}_{3} \mathrm{O}_{4} \mathrm{NPs}$ was $460 \mathrm{mg} \cdot \mathrm{g}^{-1}$ and $16,412 \pm 55 \mathrm{U} \cdot \mathrm{mg}^{-1}$ in an aqueous lysozyme solution. In addition, as demonstrated by sodium dodecyl sulfate-polyacrylamide gel electrophoresis (SDS-PAGE) electrophoresis analysis, lysozyme could be separated from crude fresh egg white using Apt- $\mathrm{NH}_{2}-\mathrm{Fe}_{3} \mathrm{O}_{4} \mathrm{NPs}$ with an amount up to $113 \pm 4.2 \mathrm{mg} \cdot \mathrm{g}^{-1}$ and an activity up to $16,370 \pm 46 \mathrm{U} \cdot \mathrm{mg}^{-1}$.
\end{abstract}

Keywords: $\mathrm{Fe}_{3} \mathrm{O}_{4}$ nanoparticle; aptamers; lysozyme; immobilization; separation

\section{Introduction}

Lysozyme is an alkaline enzyme mainly present in animals, plants, and microbes. It is usually derived from egg whites and it can damage bacterial cell walls by catalyzing the hydrolysis of 1,4-b-linkages between muramic acid and $N$-acetyl glucosamine in mucopolysaccharides [1-3]. Therefore, it is widely used as a cell-disrupting and potent anti-bacterial reagent. Lysozyme is in high demand due to its many favorable characteristics. It is naturally occurring, non-toxic, and easy to digest and absorb [4]. However, most of the lysozymes are extracted from egg white using conventional methods such as salting out, crystallization, ultrafiltration, reverse micelle extraction, ion exchange, etc. [5-7]. The above purification methods are complicated, time consuming, not widely applicable, and even some methods may denature lysozyme. Therefore, it is urgent to find a method that is both cost-effective and rapid to separate and purify lysozyme from egg white.

Recently, magnetic nanoparticles have attracted significant interest in a wide range of applications, such as cell separation, enzyme immobilization, and targeted drug administration [8-10]. Magnetic 
nanoparticles commonly contain elements such as iron, nickel, cobalt, and their alloys or oxides of magnetic elements [11-14]. The preparation of magnetic nanoparticles mainly involves chemical methods, including pyrolysis, co-precipitation, sol-gel, micro emulsion, ultrasonic chemistry, electrochemical deposition, and laser decomposition [15-18]. Magnetic nanoparticles have many advantages, such as small size, large surface area, low toxicity, biocompatibility, and superparamagnetic properties [19]. Additionally, the motion trajectory of magnetic nanoparticles can be controlled via external magnetic field conditions $[20,21]$. Therefore, there have been many studies reported in the literatures concerning the immobilization or adsorption of enzymes with ferrite nanoparticle-polymer composites [22,23]. In particular, magnetic particles known as superparamagnetic nanoparticles, with a particle size less than $30 \mathrm{~nm}$, have been shown to possess superparamagnetic properties with strong magnetic responsiveness [24]. Magnetic particles can be rapidly enriched and positioned under the action of an external magnetic field and the magnetic properties of the particles disappear rapidly when the applied magnetic field is removed. Magnetic nanoparticles have unique advantages when applied to protein immobilization and separation. Their unique magnetic properties allow them to separate and enrich their target products directly from complex systems, enabling high purity and high recovery of samples without expensive instruments and equipment. In addition, the separation process after immobilizing enzymes with magnetic nanoparticles is mild and rapid, and they have small bonding and elution power, which maintains the conformational stability and biological activity of the immobilized enzyme $[25,26]$.

Aptamers are single-stranded DNA or RNA sequences, typically $15-40$ bases in length, that are selected from a library of synthetic nucleotide combinations by SELEX (systematic evolution of ligands by exponential enrichment) techniques [27]. The aptamer can bind, with high affinity and specificity, to different molecules, including proteins, peptides, drugs, small organic molecules, and cells [28]. Aptamers also have many advantages, such as a short synthesis cycle, low cost, strong specificity, high binding, good stability, and easy modification, which have facilitated their development in many fields of medical diagnosis and treatment and biological analysis [29,30]. The aptamer of the enzyme can be chemically synthesized rapidly at a large scale using simple and low-cost preparation methods. Aptamers are generally developed in vitro using a defined iterative procedure known as systematic evolution of ligands by exponential enrichment (SELEX) [31]. These methods produce unique structures with high affinity that enable strong and stable binding between the aptamer of the enzyme and the target molecule with little effect on enzyme activity [32]. Furthermore, the specificity of the enzyme aptamer makes it possible to specifically recognize enzymes in complex systems $[33,34]$. Therefore, in this study, lysozyme was separated from egg white using magnetic nanoparticles with a lysozyme aptamer. The material was separated by the action of an external magnetic field, which typically has a high recovery rate and a low cost.

Herein, we report a new method for purification of lysozyme that exploits a selective adsorption process by magnetic nanoparticles with a lysozyme sequence aptamer (Scheme 1). Magnetic $\mathrm{Fe}_{3} \mathrm{O}_{4} \mathrm{NPs}$ were prepared by a chemical co-precipitation method and were then functionalized with amino groups using 3-aminopropyltriethoxysilane (APTES) to produce $\mathrm{NH}_{2}-\mathrm{Fe}_{3} \mathrm{O}_{4} \mathrm{NPs}$. The lysozyme aptamer was then attached to the $\mathrm{NH}_{2}-\mathrm{Fe}_{3} \mathrm{O}_{4} \mathrm{NPs}$ using a specific reaction of the aldehyde and amino groups to produce Apt- $\mathrm{NH}_{2}-\mathrm{Fe}_{3} \mathrm{O}_{4} \mathrm{NPs}$. Different adsorption conditions were tested to determine the optimal conditions for the adsorption of lysozyme in water to the prepared nanomaterials. The variables tested included initial lysozyme concentration, adsorption time, $\mathrm{pH}$, reaction temperature, and ionic strength. The Apt- $\mathrm{NH}_{2}-\mathrm{Fe}_{3} \mathrm{O}_{4} \mathrm{NPs}$ were then used for the separation of lysozyme from crude fresh egg whites. 


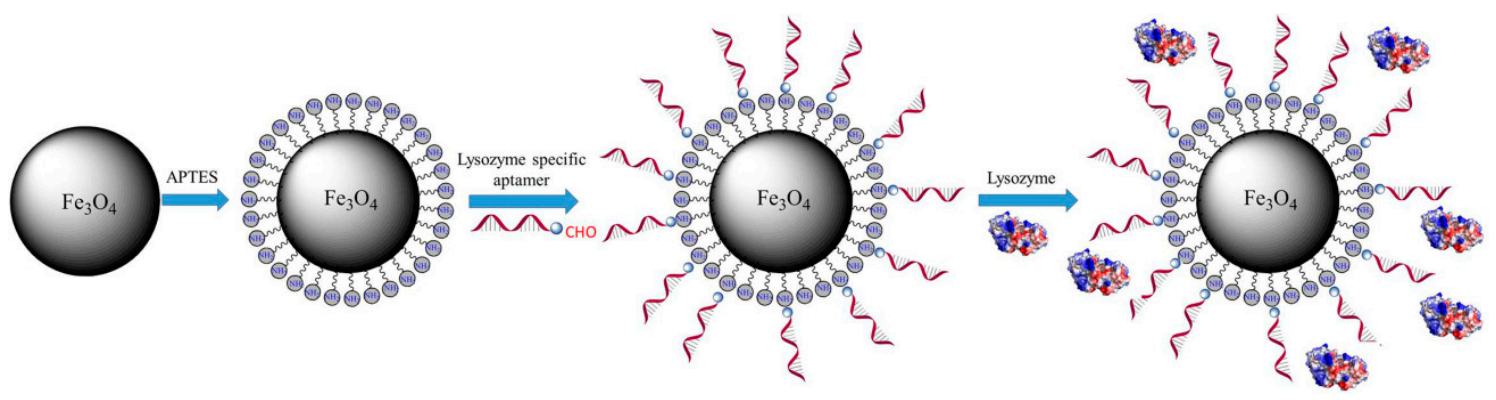

Scheme 1. Illustration of the fabrication of Apt- $\mathrm{NH}_{2}-\mathrm{Fe}_{3} \mathrm{O}_{4} \mathrm{NPs}$ for lysozyme immobilization.

\section{Materials and Methods}

\subsection{Materials}

Lysozyme was purchased from Sigma (St. Louis, MO, USA). 3-aminopropyltriethoxysilane (APTES), ferrous chloride tetrahydrate $\left(\mathrm{FeCl}_{2} \cdot 4 \mathrm{H}_{2} \mathrm{O}\right)$, ferric chloride hexahydrate $\left(\mathrm{FeCl}_{3} \cdot 6 \mathrm{H}_{2} \mathrm{O}\right)$, ammonia $(25 \%)$, sodium dihydrogen phosphate $\left(\mathrm{NaH}_{2} \mathrm{PO}_{4}\right)$, disodium hydrogen phosphate $\left(\mathrm{Na}_{2} \mathrm{HPO}_{4}\right)$, toluene, and anhydrous ethanol were purchased from Beijing Chemical Factory Reagent Company (Beijing, China). A phosphate buffer solution (PBS) was prepared using $\mathrm{NaH}_{2} \mathrm{PO}_{4}$ and $\mathrm{Na}_{2} \mathrm{HPO}_{4}$. The lysozyme-specific aptamer sequences with aldehyde modification ( $5^{\prime}$-aldehyde-TTT TTTATCAGGGCTAAAGAGTGC- $3^{\prime}$ ) were purchased from the Lianxing Biotechnology Company (Shenyang, China). Ultra-pure water with $18.2 \mathrm{M} \Omega \cdot \mathrm{cm}$ resistivity was used in all experiments. All chemicals were used as received without any further purification.

\subsection{Preparation of Nanoparticles}

Synthesis of magnetic $\mathrm{Fe}_{3} \mathrm{O}_{4}$ NPs: $\mathrm{FeCl}_{2} \cdot 4 \mathrm{H}_{2} \mathrm{O}(3 \mathrm{~g})$ and $\mathrm{FeCl}_{3} \cdot 6 \mathrm{H}_{2} \mathrm{O}(9.1 \mathrm{~g})$ were mixed in $200 \mathrm{~mL}$ of distilled water that had previously been purged with nitrogen and the solution was stirred for $10 \mathrm{~min}$. After adding $85 \mathrm{~mL}$ of ammonia $(25 \%)$, the solution was stirred at $25^{\circ} \mathrm{C}$ for $30 \mathrm{~min}$ and then heated to $70{ }^{\circ} \mathrm{C}$ with continual stirring for $30 \mathrm{~min}$ with nitrogen purge. The reaction products were collected with a magnet after the reaction system had cooled to room temperature and were repeatedly washed with distilled water to remove unreacted material. Finally, the products were freeze-dried and magnetic $\mathrm{Fe}_{3} \mathrm{O}_{4}$ NPs were obtained [19].

Synthesis of magnetic $\mathrm{NH}_{2}-\mathrm{Fe}_{3} \mathrm{O}_{4}$ NPs: The surfaces of $\mathrm{Fe}_{3} \mathrm{O}_{4}$ NPs were coated with APTES using a silanization reaction. After dissolving $4 \mathrm{~g}$ of magnetic $\mathrm{Fe}_{3} \mathrm{O}_{4}$ in $50 \mathrm{~mL}$ of anhydrous toluene, the solution was homogenized using ultrasonic waves for $15 \mathrm{~min}$ and then $22 \mathrm{mmol}$ of APTES was added via syringe. Nitrogen gas was then introduced into the reaction system, which was stirred for $5 \mathrm{~h}$ at $25^{\circ} \mathrm{C}$. After the reaction was completed, the reaction products were collected with a magnet, washed repeatedly with ethanol, and dichloromethane and freeze dried. The $\mathrm{NH}_{2}-\mathrm{Fe}_{3} \mathrm{O}_{4} \mathrm{NPs}$ were then obtained.

Synthesis of magnetic $\mathrm{NH}_{2}-\mathrm{Fe}_{3} \mathrm{O}_{4} \mathrm{NPs}$ with lysozyme aptamers (Apt- $\mathrm{NH}_{2}-\mathrm{Fe}_{3} \mathrm{O}_{4} \mathrm{NPs}$ ): $\mathrm{NH}_{2}-\mathrm{Fe}_{3} \mathrm{O}_{4} \mathrm{NPs}(1 \mathrm{~g})$ were dissolved in PBS solution $(20 \mathrm{~mL}, 0.1 \mathrm{M}, \mathrm{pH} 8.0)$ containing $10 \mathrm{nM}$ lysozyme aptamer and the mixture was shaken at $200 \mathrm{rpm}$ for $6 \mathrm{~h}$ at $35^{\circ} \mathrm{C}$. The reaction products were separated using a magnet, washed repeatedly with distilled water, and freeze dried. The magnetic Apt- $\mathrm{NH}_{2}-\mathrm{Fe}_{3} \mathrm{O}_{4} \mathrm{NPs}$ were then obtained.

\subsection{Nanoparticle Characterization}

The morphology and particle size of the magnetic $\mathrm{Fe}_{3} \mathrm{O}_{4}$ NPs were investigated by transmission electron microscopy (TEM, Tecnai G2F30; FEI, Hillsboro, OR, USA). Samples were prepared for TEM observation by ultrasonic dispersion. Take some powder sample into a centrifuge tube with ethanol and ultrasonically dispersed into a suspension. Then, a few drops of the suspended droplets were taken and dropped on a copper mesh ( $3 \mathrm{~mm}$ in diameter) using a capillary and dried to obtain a powder sample 
observed by an electron microscope. X-ray diffraction (XRD, Bruker, Karlsruhe, Germany) analysis was performed using the Bruker High-Resolution D8 Advance XRD unit with a Ni-filtered CuK $(\lambda=1.54 \AA)$. Magnetization performance of the magnetic Apt- $\mathrm{NH}_{2}-\mathrm{Fe}_{3} \mathrm{O}_{4} \mathrm{NPs}$ was characterized by measuring the hysteresis loop (Quantum Design, San Diego, CA, USA). The material was demagnetized before measuring the hysteresis loop and then the sample was magnetized to saturation, the magnetizing current was evenly reduced, and the coordinates of the hysteresis loop corresponding to different magnetization currents were recorded. The magnetic content of the Apt- $\mathrm{NH}_{2}-\mathrm{Fe}_{3} \mathrm{O}_{4} \mathrm{NPs}$ was measured using thermogravimetric analysis (TGA) with the following test conditions: rate of nitrogen purge, $100 \mathrm{~mL} \cdot \mathrm{min}^{-1}$; rate of temperature rise, $20^{\circ} \mathrm{C} \cdot \mathrm{min}^{-1}$ and temperature range, $30-900{ }^{\circ} \mathrm{C}$. The functional surface groups of Apt- $\mathrm{NH}_{2}-\mathrm{Fe}_{3} \mathrm{O}_{4} \mathrm{NPs}$ were characterized by Fourier transforms infrared spectroscopy (FTIR, IR Prestige-21; Shimadzu, Kyoto, Japan). Samples were prepared by the KBr tablet method. The $\mathrm{KBr}$ was dried at $140{ }^{\circ} \mathrm{C}$ for $5 \mathrm{~h}$ before the measurement and the ratio of the powder sample to the $\mathrm{KBr}$ powder was 1:100. The mixing sample was fully ground and compressed, which was used for infrared measurement and the spectrum range was 400 to $4000 \mathrm{~cm}^{-1}$. The corresponding potential values of Apt- $\mathrm{NH}_{2}-\mathrm{Fe}_{3} \mathrm{O}_{4} \mathrm{NPs}$ were calculated by measuring the potential values at different $\mathrm{pH}$ conditions using a zeta potential meter (Zetasizer Nano ZS 90; Malvern, UK). The magnetic Apt- $\mathrm{NH}_{2}-\mathrm{Fe}_{3} \mathrm{O}_{4} \mathrm{NPs}$ were dispersed in distilled water by ultrasonic treatment and the $\mathrm{pH}$ values of the samples were adjusted with $\mathrm{HCl}$ and $\mathrm{NaOH}$ solutions.

\subsection{Lysozyme Adsorption in an Aqueous Solution}

To measure the adsorption equilibrium of magnetic Apt- $\mathrm{NH}_{2}-\mathrm{Fe}_{3} \mathrm{O}_{4} \mathrm{NPs}, 10 \mathrm{mg}$ of material and $4 \mathrm{~mL}$ of a specific lysozyme buffer solution were mixed in a $5 \mathrm{~mL}$ centrifuge tube. Experiments were repeated at different lysozyme concentrations $\left(0.25-5.0 \mathrm{mg} \cdot \mathrm{mL}^{-1}\right)$ and at various $\mathrm{pH}$ values (4.0-11.0). Adsorption experiments were performed at a stirring speed of $180 \mathrm{rpm}$ for different times. The magnetic nanoparticles were separated from the supernatant using a magnet after the adsorption equilibrium was reached and were then washed with deionized water to remove any lysozyme that was not completely adsorbed onto the materials. The supernatant was analyzed by measuring its absorbance at $280 \mathrm{~nm}$ (the molar extinction coefficient of lysozyme at $280 \mathrm{~nm}$ is $14,301 \mathrm{M}^{-1} \cdot \mathrm{cm}^{-1}$ ), and the amount of lysozyme adsorbed was calculated by determining the lysozyme concentration in the supernatant, according to the following equation:

$$
q=\frac{V\left(C_{0}-C_{e}\right)}{m}
$$

where $q$ is the adsorption capacity of Apt- $-\mathrm{NH}_{2}-\mathrm{Fe}_{3} \mathrm{O}_{4}$ NPs to lysozyme $\left(\mathrm{mg} \cdot \mathrm{g}^{-1}\right), \mathrm{C}_{0}$ is the initial lysozyme concentration in the solution $\left(\mathrm{mg} \cdot \mathrm{mL}^{-1}\right), C_{e}$ is the lysozyme concentration at equilibrium $\left(\mathrm{mg} \cdot \mathrm{mL}^{-1}\right), m$ is the amount of $\mathrm{Apt}-\mathrm{NH}_{2}-\mathrm{Fe}_{3} \mathrm{O}_{4} \mathrm{NPs}(\mathrm{g})$, and $V$ is the volume of the lysozyme solution $(\mathrm{mL})$.

\subsection{The Separation and Purification of Lysozyme from Egg White}

Egg white liquid was initially prepared according to a previously published method [14]. The egg whites were separated from fresh eggs and were then mixed with PBS (20 mM, pH 7.2-8.0, volume ratio 1:1). The system was stirred for $6 \mathrm{~h}$ in an ice-water bath, the white flocculent precipitates were removed by centrifugation at $10,000 \mathrm{rpm}$ for $30 \mathrm{~min}$ at $4{ }^{\circ} \mathrm{C}$ and the supernatant was obtained. The supernatant was then used as the lysozyme separation solution and the purified egg white raw material solution. Next, $10 \mathrm{mg}$ of Apt- $\mathrm{NH}_{2}-\mathrm{Fe}_{3} \mathrm{O}_{4} \mathrm{NPs}$ was added to $1 \mathrm{~mL}$ of the lysozyme separation solution and the mixture was stirred at $180 \mathrm{rpm}$ for $60 \mathrm{~min}$ at $37^{\circ} \mathrm{C}$. The magnetic nanoparticles were then separated by a magnet and washed several times with deionized water to remove unabsorbed substances. The collected magnetic nanoparticle adsorbed with lysozyme was stored at $-20{ }^{\circ} \mathrm{C}$ for the next elution test and further assayed for the activity of the isolated lysozyme. The supernatant was analyzed by measuring its absorbance at $280 \mathrm{~nm}$ and the amount of lysozyme adsorbed was calculated by determining the lysozyme concentration in the supernatant. 


\subsection{Lysozyme Desorption}

After separating lysozyme from egg white, the Apt- $-\mathrm{NH}_{2}-\mathrm{Fe}_{3} \mathrm{O}_{4} \mathrm{NPs}$ were subjected to a desorption test. The nanoparticles were added to a glycine solution $(0.2 \mathrm{M}, \mathrm{pH} 2.0)$ and the eluate was collected and analyzed for concentration, purity, and enzyme activity.

\subsection{SDS Gel Electrophoresis}

The purity of the eluate was measured using sodium dodecyl sulfate-polyacrylamide gel electrophoresis (SDS-PAGE) with a $12 \%$ polyacrylamide separation gel and an $8 \%$ polyacrylamide concentration gel.

\subsection{Activity of Lysozyme after Separation}

The freeze-dried bacterial strains were first resuscitated and activated. Then, their optical density at $450 \mathrm{~nm}\left(\mathrm{OD}_{450}\right)$ was adjusted to 1.3 by diluting the bacterial solution in PBS (0.1 M, pH 7.2-8.0). After dissolving $10 \mathrm{mg}$ of lysozyme in $1 \mathrm{~mL}$ of PBS $(0.1 \mathrm{M}, \mathrm{pH} 6.24)$, it was then diluted to $100 \mathrm{U} \cdot \mathrm{mL}^{-1}$ and $0.5 \mathrm{~mL}$ of this standard enzyme solution was added to $2.5 \mathrm{~mL}$ of the aforementioned bacterial solution. The decrease in absorbance per minute was measured using a microplate reader. Lysozyme activity was calculated using the equation below:

$$
\text { Lysozyme activity }\left(\frac{\mathrm{U}}{\mathrm{mg}}\right)=\frac{\text { Initial absorbance }- \text { Final absorbance }}{0.001 \times t(\mathrm{~min}) \times \text { Lysozyme quality }(\mathrm{mg})} \text {. }
$$

\section{Results and Discussion}

\subsection{Characterization of the Prepared Nanoparticles}

The morphology of the $\mathrm{Fe}_{3} \mathrm{O}_{4}$ NPs was determined by TEM images (Figure 1). TEM images (Figure 1A-C) and size distribution histogram of the synthesized $\mathrm{Fe}_{3} \mathrm{O}_{4}$ NPs (Figure 1D) showed that the magnetic $\mathrm{Fe}_{3} \mathrm{O}_{4}$ nanoparticles had a uniform diameter of about $19 \mathrm{~nm}$ and had a spherical shape with a smooth surface. They also showed that the magnetic $\mathrm{Fe}_{3} \mathrm{O}_{4} \mathrm{NPs}$ had good dispersion, with basically single layer dispersion.
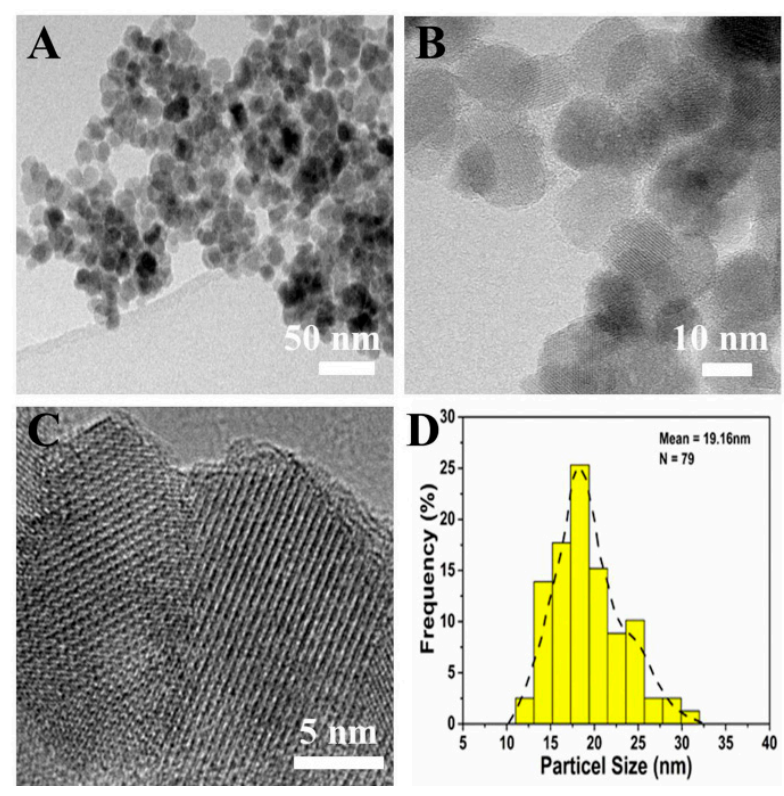

Figure 1. Transmission electron microscopy (TEM) images of $\mathrm{Fe}_{3} \mathrm{O}_{4} \mathrm{NPs}(\mathrm{A}-\mathrm{C})$ and size distribution histogram (D) of the synthesized $\mathrm{Fe}_{3} \mathrm{O}_{4}$ NPs. 
As shown in Figure 2A, a, b, and c represent the XRD patterns of the $\mathrm{Fe}_{3} \mathrm{O}_{4}, \mathrm{NH}_{2}-\mathrm{Fe}_{3} \mathrm{O}_{4}$, and Apt- $\mathrm{NH}_{2}-\mathrm{Fe}_{3} \mathrm{O}_{4} \mathrm{NPs}$, respectively, which have the same crystal face characteristic diffraction peaks of (220), (311), (400), (422), (511), (440) that were present at 30.49, 35.66, 43.25, 53.65, 57.32, 63.02, respectively, which indicated that the $\mathrm{Fe}_{3} \mathrm{O}_{4} \mathrm{NPs}$ were synthesized successfully [35]. In addition, this also showed that the diffraction peaks of $\mathrm{Fe}_{3} \mathrm{O}_{4}$ NPs did not change after amino functionalization and grafting of lysozyme aptamers. It was proved that the good crystal structure and good magnetic properties of the nanoparticles were maintained, thus ensuring the magnetic separation of the adsorbent in the experiment.
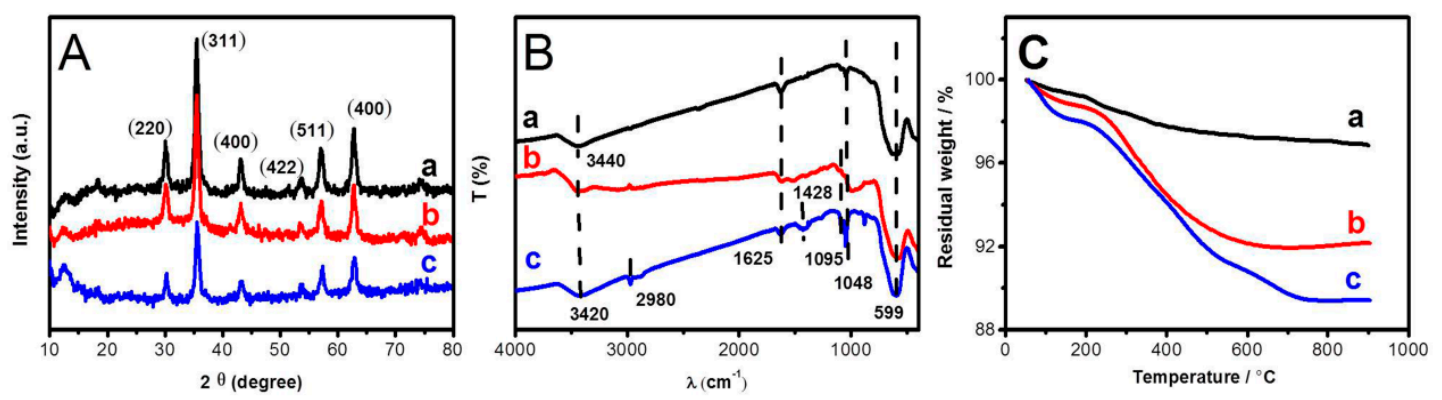

Figure 2. The $\mathrm{X}$-ray diffraction $(\mathrm{XRD}, \mathrm{A})$, Fourier transform infrared spectroscopy (FTIR, B), and thermogravimetric analysis (TGA, C) data for $\mathrm{Fe}_{3} \mathrm{O}_{4}(\mathrm{a}), \mathrm{NH}_{2}-\mathrm{Fe}_{3} \mathrm{O}_{4}$ (b), and Apt- $\mathrm{NH}_{2}-\mathrm{Fe}_{3} \mathrm{O}_{4} \mathrm{NPs}$ (c).

As shown in Figure 2B, the surface groups were characterized by FTIR absorption peaks in the range of $400-4000 \mathrm{~cm}^{-1}$. The characteristic absorption peak of $\mathrm{Fe}-\mathrm{O}$ at $599 \mathrm{~cm}^{-1}$ was seen, indicating that $\mathrm{Fe}_{3} \mathrm{O}_{4}$ NPs were successfully synthesized. The stretching vibration peaks of the $\mathrm{Si}-\mathrm{O}$ bond were observed at $1048 \mathrm{~cm}^{-1}$ and $1095 \mathrm{~cm}^{-1}$, indicating that a Si-O bond existed on the surface of the $\mathrm{NH}_{2}-\mathrm{Fe}_{3} \mathrm{O}_{4}$ and Apt- $\mathrm{NH}_{2}-\mathrm{Fe}_{3} \mathrm{O}_{4} \mathrm{NPs}$. The stretching vibration peaks of the $\mathrm{C}-\mathrm{N}$ bond were observed at $1428 \mathrm{~cm}^{-1}$ and a vibration peak associated to imine formation between aldehyde of aptamer and $\mathrm{NH}_{2}$ is visible at $1625 \mathrm{~cm}^{-1}$, indicating that aptamer functionalized on the Apt- $\mathrm{NH}_{2}-\mathrm{Fe}_{3} \mathrm{O}_{4} \mathrm{NPs}$. The vibration peaks observed at $3440 \mathrm{~cm}^{-1}$ on $\mathrm{Fe}_{3} \mathrm{O}_{4} \mathrm{NPs}$ may be attributed to $-\mathrm{OH}$. The significant vibration peaks observed at $3420 \mathrm{~cm}^{-1}$ and $2980 \mathrm{~cm}^{-1}$ represented $-\mathrm{NH}$ and $-\mathrm{CH}_{2}$, indicating that $\mathrm{Fe}_{3} \mathrm{O}_{4}$ NPs were successfully functionalized with amino groups by APTES, and which demonstrated that silica was successfully encapsulated on the surface of $\mathrm{Fe}_{3} \mathrm{O}_{4} \mathrm{NPs}$. This can prevent agglomeration of the magnetic nanoparticles.

As shown in Figure 2C, a, b, and c represent the TGA curves of the $\mathrm{Fe}_{3} \mathrm{O}_{4}, \mathrm{NH}_{2}-\mathrm{Fe}_{3} \mathrm{O}_{4}$, and Apt- $\mathrm{NH}_{2}-\mathrm{Fe}_{3} \mathrm{O}_{4} \mathrm{NPs}$, respectively. The process of weight loss of $\mathrm{Fe}_{3} \mathrm{O}_{4} \mathrm{NPs}$ could be divided into two relatively independent processes. The first weight loss process took place at $50-200{ }^{\circ} \mathrm{C}$ and the weight loss of $0.8 \%$, mainly due to the evaporation of water. The second process occurred at $200-650{ }^{\circ} \mathrm{C}$ with a weight loss of $1.9 \%$, mainly due to the decomposition of the surface groups of the $\mathrm{Fe}_{3} \mathrm{O}_{4} \mathrm{NPs}$. The TGA curve of $\mathrm{NH}_{2}-\mathrm{Fe}_{3} \mathrm{O}_{4} \mathrm{NPs}$ could be divided into two relatively independent processes. The first weight loss process took place at $50-210{ }^{\circ} \mathrm{C}$ and the weight loss was $1.4 \%$, which was mainly due to the decomposition of the surface groups on the magnetic nanoparticles. The second process took place at $210-650{ }^{\circ} \mathrm{C}$ with a weight loss of $6.5 \%$, mainly due to the decomposition of the surface groups of the $\mathrm{NH}_{2}-\mathrm{Fe}_{3} \mathrm{O}_{4} \mathrm{NPs}$. The TGA curve of the Apt- $\mathrm{NH}_{2}-\mathrm{Fe}_{3} \mathrm{O}_{4} \mathrm{NPs}$ was shown in Figure $2 \mathrm{C}$ (c). The process of weight loss could be divided into three relatively independent processes. The first weight loss process occurred at $25-220^{\circ} \mathrm{C}$ and involved a loss of $2.26 \%$, which was mainly due to the evaporation of water. The second process occurred at $220-700{ }^{\circ} \mathrm{C}$ and involved a weight loss of $10.25 \%$, which was mainly due to the decomposition of the surface groups on the magnetic nanoparticles. The last process occurred at $700-900{ }^{\circ} \mathrm{C}$, but the weight loss was not significant, indicating that the $\mathrm{Fe}_{3} \mathrm{O}_{4}$ content of the magnetic core was about $89.4 \%$. These magnetic nanoparticles contained higher $\mathrm{Fe}_{3} \mathrm{O}_{4}$ content and stronger magnetic force. 
Figure $3 \mathrm{~A}$ shows the hysteresis loops of the Apt $-\mathrm{NH}_{2}-\mathrm{Fe}_{3} \mathrm{O}_{4} \mathrm{NPs}$, from which it was observed that the magnetic nanoparticle had a magnetic saturation of $70.9 \mathrm{emu} \cdot \mathrm{g}^{-1}$ and the magnetic nanoparticle particles did not exhibit coercivity with an applied magnetic field. As shown in Figure 3A, the hysteresis loop was an S-type loop with a coercive force tending to 0 , indicating that the magnetic material had superparamagnetic properties that could prevent the agglomeration of the nanoparticles [19]. The zeta potential of the Apt- $\mathrm{NH}_{2}-\mathrm{Fe}_{3} \mathrm{O}_{4} \mathrm{NPs}$ is shown in Figure 3B. As the magnetic nanoparticles had different groups on their surface, the zeta potentials at different $\mathrm{pH}$ values were not the same. The isoelectric point of the magnetic nanoparticles was about 7.6, as shown in Figure 3B. Therefore, when the $\mathrm{pH}$ of the solution was greater than 7.6, the magnetic nanoparticles were negatively charged. Lysozyme is positively charged at $\mathrm{pH}$ values less than 11.2 (the isoelectric point of lysozyme is approximately 11.2), indicating that magnetic nanoparticles could combine with lysozyme via electrostatic attraction when the $\mathrm{pH}$ of the solution was in the range 7.6-11.2.
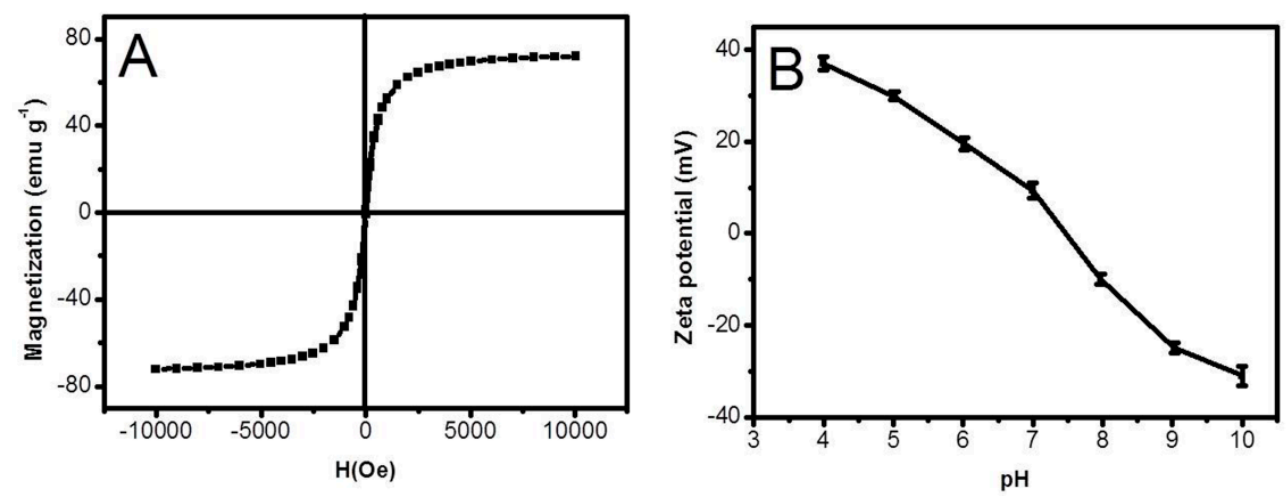

Figure 3. Hysteresis loop (A) and zeta potential (B) of Apt- $\mathrm{NH}_{2}-\mathrm{Fe}_{3} \mathrm{O}_{4} \mathrm{NPs}$.

\subsection{Adsorption of Lysozyme to Apt- $\mathrm{NH}_{2}-\mathrm{Fe}_{3} \mathrm{O}_{4}$ Nanoparticles}

Effect of initial concentration, adsorption time, $\mathrm{pH}$, temperature, and ionic strength: To determine the optimal conditions for lysozyme adsorption onto Apt- $\mathrm{NH}_{2}-\mathrm{Fe}_{3} \mathrm{O}_{4} \mathrm{NPs}$, the initial lysozyme concentration, absorption time, $\mathrm{pH}$ value, temperature, and ionic strength were evaluated. The effect of initial lysozyme concentration was shown in Figure 4A. The amount of lysozyme adsorption increased with the initial lysozyme concentration, until it approached a maximum at a concentration of $4.0 \mathrm{mg} \cdot \mathrm{mL}^{-1}$. This concentration maximum could be attributed to the saturation of binding sites on the Apt- $\mathrm{NH}_{2}-\mathrm{Fe}_{3} \mathrm{O}_{4}$ NPs. The effect of adsorption time on the lysozyme immobilization was studied at a lysozyme concentration of $4.0 \mathrm{mg} \cdot \mathrm{mL}^{-1}$ and the temperature was $37^{\circ} \mathrm{C}$. The experimental results showed that the adsorption time reached the maximum at $60 \mathrm{~min}$ (Figure 4B). A range of $\mathrm{pH}$ values between 4.0 and 11.0 were tested and the optimum $\mathrm{pH}$ value for enzyme immobilization by Apt- $\mathrm{NH}_{2}-\mathrm{Fe}_{3} \mathrm{O}_{4} \mathrm{NPs}$ was found to be 9.0 (Figure $4 \mathrm{C}$ ). Generally, the maximum adsorption of a protein is observed at its isoelectric point, which is $\mathrm{pH} 11.2$ for lysozyme. However, maximum adsorption in this study was found to occur at $\mathrm{pH} 9.0$, which may be due to the positive charge of lysozyme and the negative charge of Apt- $\mathrm{NH}_{2}-\mathrm{Fe}_{3} \mathrm{O}_{4} \mathrm{NPs}$ at this $\mathrm{pH}$ [36]. Therefore, the $\mathrm{pH}$-dependent adsorption of lysozyme by Apt- $\mathrm{NH}_{2}-\mathrm{Fe}_{3} \mathrm{O}_{4} \mathrm{NPs}$ indicated that electrostatic attraction was the major force for lysozyme immobilization onto Apt- $\mathrm{NH}_{2}-\mathrm{Fe}_{3} \mathrm{O}_{4} \mathrm{NPs}$. The effect of temperature on lysozyme adsorption was studied by varying temperatures between 30 and $42{ }^{\circ} \mathrm{C}$ (Figure 4D). The optimal temperature was found to be $37^{\circ} \mathrm{C}$. Temperature affected the rate of molecular movement and influenced interactions between proteins. Amino acid residues that are usually buried within the protein may have become exposed on the surface at higher temperatures, resulting in an increase in the binding sites of the protein for the adsorbent. In addition, the $\mathrm{NaCl}$ solution was added to the solution to adjust the ionic strength. The $\mathrm{NaCl}$ concentration was $0 \mathrm{M}$ and $1 \mathrm{M}$, respectively. The experimental results are shown in Figure S1. It was known that with the increase of ionic strength, the adsorption capacity of magnetic Apt- $\mathrm{NH}_{2}-\mathrm{Fe}_{3} \mathrm{O}_{4}$ nanoparticles for lysozyme got worse. Since 
the ionic strength of the solution was increased, the electrostatic force between the carrier and the lysozyme was reduced and the hydrophobic action was enhanced such that the adsorption was not favorable. Studies have shown that as the salt concentration increases, it would also cause the salting out reaction of the protein and then cause aggregation and precipitation. Therefore, it was concluded that in the adsorption process, $0 \mathrm{M} \mathrm{NaCl}$ was added, which was the optimal adsorption reaction condition. Under optimum immobilization conditions, the amount of immobilized lysozyme was $460 \pm 3.4 \mathrm{mg} \cdot \mathrm{g}^{-1}$ and the activity of the immobilized lysozyme was $16,412 \pm 55 \mathrm{U} \cdot \mathrm{mg}^{-1}$. This was a higher carrier capacity than those previously reported in the literature, probably due to the specificity of the lysozyme aptamer and the magnetic properties of $\mathrm{Fe}_{3} \mathrm{O}_{4}$ NPs (Table 1) [37-40]. In addition, the lysozyme immobilization experiment using $\mathrm{Fe}_{3} \mathrm{O}_{4} \mathrm{NPs}$ and $\mathrm{NH}_{2}-\mathrm{Fe}_{3} \mathrm{O}_{4} \mathrm{NPs}$ under the optimal conditions were carried out for evaluating this adsorption process. The research showed that this adsorption process is not non-selective adsorption, $\mathrm{Fe}_{3} \mathrm{O}_{4} \mathrm{NPs}$ and $\mathrm{NH}_{2}-\mathrm{Fe}_{3} \mathrm{O}_{4} \mathrm{NPs}$ can also achieve lysozyme immobilization, but the immobilization was lower as 218.39 and $211.35 \mathrm{mg} \cdot \mathrm{g}^{-1}$, respectively. Therefore, the Apt- $\mathrm{NH}_{2}-\mathrm{Fe}_{3} \mathrm{O}_{4} \mathrm{NPs}$ have higher loading capacity and better performance.
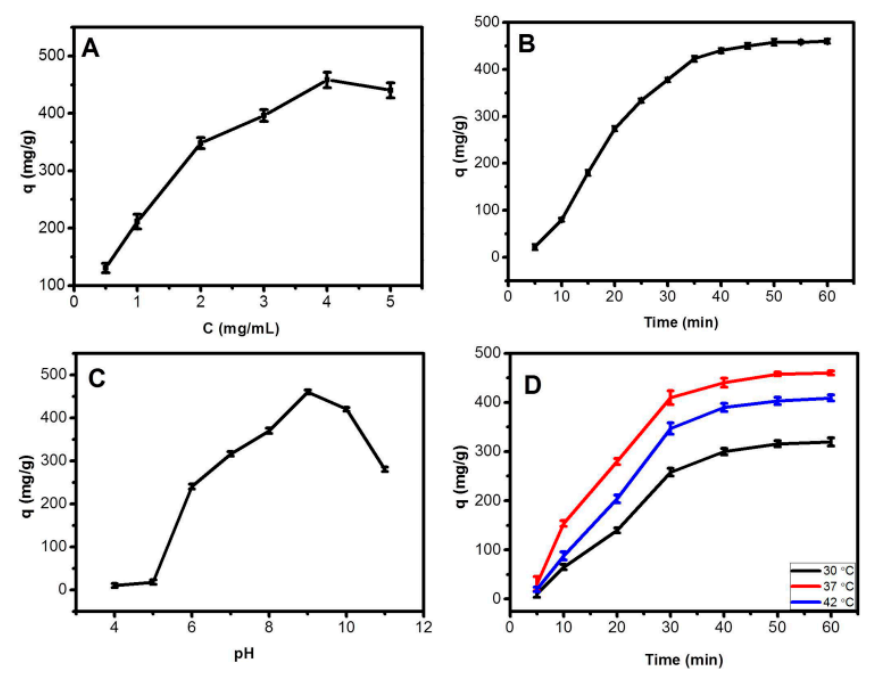

Figure 4. The effect of initial concentration $(\mathbf{A})$, adsorption time $(\mathbf{B}), \mathrm{pH}(\mathbf{C})$, and reaction temperature (D) on the lysozyme immobilization by Apt- $\mathrm{NH}_{2}-\mathrm{Fe}_{3} \mathrm{O}_{4} \mathrm{NPs}$.

Table 1. Comparisons of the amount of immobilized lysozyme.

\begin{tabular}{ccc}
\hline Immobilized Enzyme Carrier & Lysozyme Adsorption Capacity $\left(\mathbf{m g} \cdot \mathbf{g}^{\mathbf{- 1}}\right.$ ) & References \\
\hline $\begin{array}{c}\text { The hydrophobic affinity ligand l-tryptophan } \\
\text { immobilized magnetic poly(glycidyl methacrylate) } \\
\text { [m-poly(GMA)] beads }\end{array}$ & 259.6 & {$[37]$} \\
\hline $\begin{array}{c}\text { Magnetic poly(2-hydroxyethyl methacrylate) } \\
\text { mPHEMA beads carrying Cibacron Blue F3GA } \\
\text { (mPHEMA/Cibacron Blue F3GA beads) }\end{array}$ & 342 & {$[38]$} \\
\hline $\begin{array}{c}\text { Macroporous chitosan }(\mathrm{CS}) / \text { carboxymethylcellulose } \\
(\mathrm{CMC}) \text { blend membranes beads }\end{array}$ & 240 & {$[39]$} \\
\hline $\begin{array}{c}\text { Chitosan }(\mathrm{CS}) / \text { hydroxyapatite (HAP) hybrid } \\
\text { membrane }\end{array}$ & 203.9 & {$[40]$} \\
\hline Apt- $\mathrm{NH}_{2}-\mathrm{Fe}_{3} \mathrm{O}_{4} \mathrm{NPs}$ & 460 & This work \\
\hline
\end{tabular}

Adsorption isotherms: The adsorption behavior of a lysozyme solution is usually described using the Langmuir and Freundlich isotherm models. The most suitable isotherm model for the data in this study was determined by comparing the correlation coefficients $\left(r^{2}\right)$ of the two models. 
The Langmuir curve assumes that the adsorption process is a monolayer, which is applicable to a homogeneous adsorption surface where all adsorption sites have equal adsorbate affinity. It is represented by the following equation [41]:

$$
\frac{1}{q_{e}}=\frac{1}{q_{\max }}+\frac{1}{q_{\max } b C_{e}}
$$

The Freundlich isotherm model assumes heterogeneity of adsorption surfaces and is expressed by the following equation [42]:

$$
\ln q_{e}=\frac{1}{n} \ln C e+\ln K_{F},
$$

where, $C_{e}$ is the concentration of lysozyme in the solution $\left(\mathrm{mg} \cdot \mathrm{mL}^{-1}\right), q_{e}$ is the amount adsorbed at the concentration equilibrium state $\left(\mathrm{mg} \cdot \mathrm{g}^{-1}\right), q_{\max }$ is the maximum adsorption capacity at equilibrium $\left(\mathrm{mg} \cdot \mathrm{g}^{-1}\right)$, and $b$ is the adsorption constant.

Figure 5 shows the Langmuir (A) and Freundlich (B) isotherm curves for lysozyme adsorption by Apt- $\mathrm{NH}_{2}-\mathrm{Fe}_{3} \mathrm{O}_{4}$ NPs. The parameters of Langmuir and Freundlich are shown in the Table 2. The $r^{2}$ obtained from the Langmuir model was slightly higher than that obtained from the Freundlich model, indicating that lysozyme adsorption by Apt- $\mathrm{NH}_{2}-\mathrm{Fe}_{3} \mathrm{O}_{4} \mathrm{NPs}$ may be explained using the Langmuir model.
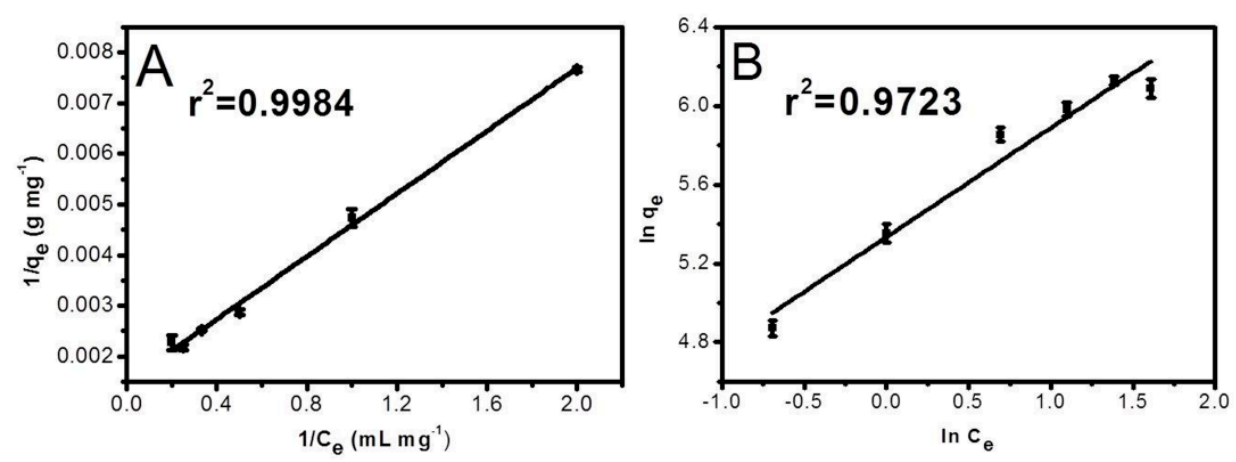

Figure 5. The Langmuir isotherm (A) and Freundlich isotherm (B) curves for lysozyme adsorption onto Apt- $\mathrm{NH}_{2}-\mathrm{Fe}_{3} \mathrm{O}_{4} \mathrm{NPs}$.

\begin{tabular}{|c|c|c|c|c|c|}
\hline \multicolumn{3}{|c|}{ Langmuir Adsorption Isotherm } & \multicolumn{3}{|c|}{ Freundlich Adsorption Isotherm } \\
\hline$q_{e}\left(\mathrm{mg} \cdot \mathrm{g}^{-1}\right)$ & $b\left(\mathrm{~mL} \cdot \mathrm{mg}^{-1}\right)$ & $r^{2}$ & $K_{F}$ & $1 / n$ & $r^{2}$ \\
\hline 666 & 2.067 & 0.9984 & 0.5546 & 1.803 & 0.9723 \\
\hline
\end{tabular}

Table 2. Langmuir and Freundlich parameters for adsorption of lysozyme onto Apt- $\mathrm{NH}_{2}-\mathrm{Fe}_{3} \mathrm{O}_{4} \mathrm{NPs}$.

Adsorption kinetics modeling: In order to examine the controlling mechanism of the lysozyme adsorption process based on Apt- $\mathrm{NH}_{2}-\mathrm{Fe}_{3} \mathrm{O}_{4} \mathrm{NPs}$, this experiment was investigated. According to the experimental conditions optimized in the above experiments, we weighed $10 \mathrm{mg}$ of magnetic $\mathrm{Fe}_{3} \mathrm{O}_{4}$ nanoparticles and $4 \mathrm{~mL}$ of $4 \mathrm{mg} \cdot \mathrm{mL}^{-1}$ lysozyme solution in a $5 \mathrm{~mL}$ centrifuge tube at $37^{\circ} \mathrm{C}$ and shook it for $120 \mathrm{~min}$ at $180 \mathrm{rpm}$. The kinetic models can be used in this case assuming that the measured concentrations are equal to the adsorbent surface concentrations [43]. The quasi-first-order kinetic model is one of the most widely used kinetic equations. It is represented by the following equation:

$$
\frac{1}{q_{t}}=\left(\frac{k_{1}}{q_{1}}\right)\left(\frac{1}{t}\right)+\frac{1}{q_{1}}
$$

where $q_{t}$ is the adsorption amount at different times $\left(\mathrm{mg} \cdot \mathrm{g}^{-1}\right), q_{1}$ is the equilibrium adsorption amount obtained by fitting $\left(\mathrm{mg} \cdot \mathrm{g}^{-1}\right)$, and $k_{1}$ is the first-order reaction rate constant $\left(\mathrm{min}^{-1}\right)$. 
The quasi-second-order kinetic model is also commonly used to describe and analyze the adsorption of lysozyme. From this model, it is possible to deduce whether the surface reaction is a rate control step. It is represented by the following equation [44]:

$$
\frac{t}{q_{t}}=\frac{1}{k_{2} q_{2}^{2}}+\frac{t}{q_{2}}
$$

where $q_{t}$ is the adsorption amount at different times $\left(\mathrm{mg}^{\circ} \mathrm{g}^{-1}\right), q_{2}$ is the equilibrium adsorption amount obtained by fitting $\left(\mathrm{mg} \cdot \mathrm{g}^{-1}\right), k_{2}$ is the second-order reaction rate constant $\left(\mathrm{g} \cdot \mathrm{mg}^{-1} \cdot \mathrm{min}^{-1}\right)$, and $k_{2} q_{2}{ }^{2}$ is the initial adsorption rate $\left(\mathrm{mg} \cdot \mathrm{g}^{-1} \cdot \mathrm{min}^{-1}\right)$.

The fitting curves of the quasi-first-order and quasi-second-class models are shown in Figure 6B,C and the fitting curve parameters are listed in Table 3. The $r^{2}$ value of the quasi-secondary model (0.9921) was compared with the quasi-first-order model (0.8545) was larger and closer to 1 , and the experimental values $\left(460 \pm 3.4 \mathrm{mg} \cdot \mathrm{g}^{-1}\right)$ of the equilibrium adsorption amount and the calculated values $q_{2}$ of the quasi-secondary model agreed well, indicating that the quasi-secondary model is better to predict the adsorption kinetics of lysozyme on Apt- $\mathrm{NH}_{2}-\mathrm{Fe}_{3} \mathrm{O}_{4} \mathrm{NPs}$.


Figure 6. Adsorption kinetics curves (A), simulation curves of pseudo-first-order (B) and pseudo-second-order (C) models of lysozyme onto Apt- $\mathrm{NH}_{2}-\mathrm{Fe}_{3} \mathrm{O}_{4} \mathrm{NPs}$.

Table 3. Kinetic parameters for the adsorption of lysozyme onto Apt- $\mathrm{NH}_{2}-\mathrm{Fe}_{3} \mathrm{O}_{4} \mathrm{NPs}$.

\begin{tabular}{|c|c|c|c|c|c|c|}
\hline \multicolumn{3}{|c|}{ Pseudo-First-Order } & \multicolumn{4}{|c|}{ Pseudo-Second-Order } \\
\hline$q_{1}\left(\mathrm{mg} \cdot \mathrm{g}^{-1}\right)$ & $k_{1}\left(\min ^{-1}\right)$ & $r^{2}$ & $q_{2}\left(\mathrm{mg} \cdot \mathrm{g}^{-1}\right)$ & $k_{2}\left(\mathrm{~g} \cdot \mathrm{mg}^{-1} \cdot \min ^{-1}\right)$ & $k_{2} q_{2}^{2}\left(\mathrm{mg} \cdot \mathrm{g}^{-1} \cdot \mathrm{min}^{-1}\right)$ & $r^{2}$ \\
\hline 555.56 & 15 & 0.8545 & 526.32 & 0.000227 & 62.89 & 0.9921 \\
\hline
\end{tabular}

Separation of lysozyme from egg white using Apt- $\mathrm{NH}_{2}-\mathrm{Fe}_{3} \mathrm{O}_{4} \mathrm{NPs}$ : As seen in Figure $7 \mathrm{c}$, there are several main proteins in egg white and a band of lysozyme could be clearly seen in the eluant after the adsorption and desorption by Apt- $\mathrm{NH}_{2}-\mathrm{Fe}_{3} \mathrm{O}_{4} \mathrm{NPs}$. This indicated that the lysozyme concentration in egg white was high and that the magnetic Apt- $\mathrm{NH}_{2}-\mathrm{Fe}_{3} \mathrm{O}_{4} \mathrm{NPs}$ could separate lysozyme from the egg white (Figure $7 \mathrm{~d}$ ). In addition, the amount of lysozyme separated was $113 \pm 4.2 \mathrm{mg} \cdot \mathrm{g}^{-1}$, and the activity of the separated lysozyme was $16,370 \pm 46 \mathrm{U} \cdot \mathrm{mg}^{-1}$. The conventional separation/purification methods for lysozyme are ultra-filtration, precipitation, and chromatography. We present a simple one-step purification of lysozyme from whole chicken egg white samples. The resulting Apt- $\mathrm{NH}_{2}-\mathrm{Fe}_{3} \mathrm{O}_{4} \mathrm{NPs}$ possessed an excellent adsorption and purification of lysozyme. It is easy to recycle and can be reused many times.

\subsection{Lysozyme Activity Assays}

The absorbance value at $450 \mathrm{~nm}$ was measured using a microplate reader. Standard enzyme activity was calculated to be $18,400 \pm 53 \mathrm{U} \cdot \mathrm{mg}^{-1}$ according to the difference in absorbance before and after the reaction. The activity of the separated lysozyme from egg crude was $16,370 \pm 46 \mathrm{U} \cdot \mathrm{mg}^{-1}$. 


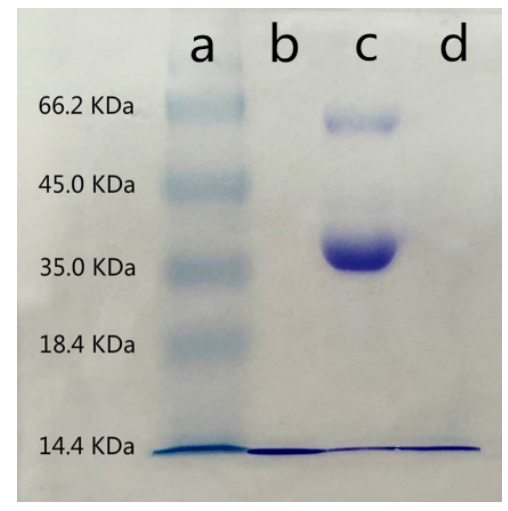

Figure 7. SDS gel electrophoresis of lysozyme separated from whole egg white: (a) protein standard markers, (b) commercial lysozyme, (c) total whole egg white before adsorption, and (d) lysozyme eluted from the Apt- $\mathrm{NH}_{2}-\mathrm{Fe}_{3} \mathrm{O}_{4} \mathrm{NPs}$.

\section{Conclusions}

To summarize, magnetic $\mathrm{Fe}_{3} \mathrm{O}_{4}$ NPs were successfully synthesized and were functionalized with amino and lysozyme aptamers to finally obtain Apt- $\mathrm{NH}_{2}-\mathrm{Fe}_{3} \mathrm{O}_{4} \mathrm{NPs}$ for the separation of lysozyme. The resulting Apt- $\mathrm{NH}_{2}-\mathrm{Fe}_{3} \mathrm{O}_{4}$ NPs possessed an excellent adsorption of lysozyme in water, with a maximum adsorption capacity of $460 \pm 3.4 \mathrm{mg} \cdot \mathrm{g}^{-1}$ and activity of the immobilized lysozyme was $16,412 \pm 55 \mathrm{U} \cdot \mathrm{mg}^{-1}$ under the optimal conditions. The optimum initial lysozyme concentration, adsorption time, $\mathrm{pH}$, and reaction temperature were $4 \mathrm{mg} \cdot \mathrm{mL}^{-1}, 60 \mathrm{~min}, 9.0$, and $37^{\circ} \mathrm{C}$, respectively. Furthermore, the lysozyme adsorption process using Apt- $\mathrm{NH}_{2}-\mathrm{Fe}_{3} \mathrm{O}_{4} \mathrm{NPs}$ could be explained using the Langmuir model and a quasi-first-order kinetic model. In addition, Apt- $\mathrm{NH}_{2}-\mathrm{Fe}_{3} \mathrm{O}_{4} \mathrm{NPs}$ could be successfully used to separate lysozyme from egg white with an amount up to $113 \pm 4.2 \mathrm{mg} \cdot \mathrm{g}^{-1}$, and the activity of the separated lysozyme was $16,370 \pm 46 \mathrm{U} \cdot \mathrm{mg}^{-1}$. The isolated lysozyme showed high activity and purity. Its purity was demonstrated using SDS-PAGE electrophoresis analysis. The method described here for adsorption and separating enzymes is simple, specific, mild, uses magnetic separation, and has potential in the food field.

Supplementary Materials: The following are available online at http://www.mdpi.com/2304-8158/8/2/67/s1, Figure S1: The effect of ionic strength on the lysozyme immobilization using Apt- $\mathrm{NH}_{2}-\mathrm{Fe}_{3} \mathrm{O}_{4} \mathrm{NPs}$.

Author Contributions: Data curation, R.L., X.Z., Y.C., S.T., and F.J.; Formal analysis, R.L. and F.P.; Investigation, S.T.; Methodology, R.L., X.Z., Y.C., F.J., X.N., F.P., and H.W.; Supervision, H.W.; Writing-original draft, R.L., F.P., and H.W.; Writing-review and editing, R.L. and H.W.

Funding: Supported by the Key Program of Jilin Province (20180201044NY) and by the Foundation of Jilin Educational Committee (3D518L714071).

Conflicts of Interest: The authors declare no conflict of interest.

\section{References}

1. Lockey, T.D.; Ourth, D.D. Purification and characterization of lysozyme from hemolymph of Heliothis virescens larvae. Biochem. Biophys. Res. Commun. 1996, 220, 502-508. [CrossRef] [PubMed]

2. Pellegrini, A.; Thomas, U.; Fellenberg, R.V.; Wild, P. Bactericidal activities of lysozyme and aprotinin against gram-negative and gram-positive bacteria related to their basic character. J. Appl. Microbiol. 2010, 72, 180-187. [CrossRef]

3. Parry, R.M., Jr.; Chandan, R.C.; Shahani, K.M. Isolation and characterization of human milk lysozyme. Arch. Biochem. Biophys. 1969, 130, 59-65. [CrossRef]

4. Wang, Q.; Fan, X.; Hu, Y.; Yuan, J.; Cui, L.; Wang, P. Antibacterial functionalization of wool fabric via immobilizing lysozymes. Bioprocess Biosyst. Eng. 2009, 32, 633-639. [CrossRef] [PubMed] 
5. Thammasirirak, S.; Ponkham, P.; Preecharram, S.; Khanchanuan, R.; Phonyothee, P.; Daduang, S.; Srisomsap, C.; Araki, T.; Svasti, J. Purification, characterization and comparison of reptile lysozymes. Comp. Biochem. Physiol. C 2006, 143, 209-217. [CrossRef]

6. Noh, K.H.; Imm, J.Y. One-step separation of lysozyme by reverse micelles formed by the cationic surfactant, cetyldimethylammonium bromide. Food Chem. 2005, 93, 95-101. [CrossRef]

7. Xue, Q.G.; Schey, K.L.; Volety, A.K.; Chu, F.L.; La Peyre, J.F. Purification and characterization of lysozyme from plasma of the eastern oyster (Crassostrea virginica). Comp. Biochem. Physiol. B 2004, 139, 11-25. [CrossRef]

8. Pratsinis, S.E.; Vemury, S. Particle formation in gases: A review. Powder Technol. 1996, 88, 267-273. [CrossRef]

9. Zeng, L.; Luo, K.; Gong, Y. Preparation and characterization of dendritic composite magnetic particles as a novel enzyme immobilization carrier. J. Mol. Catal. B Enzym. 2006, 38, 24-30. [CrossRef]

10. Koc, K.; Alveroglu, E. Adsorption and desorption studies of lysozyme by $\mathrm{Fe}_{3} \mathrm{O}_{4}$-polymer nanocomposite via fluorescence spectroscopy. J. Mol. Struct. 2015, 1089, 66-72. [CrossRef]

11. Melo, R.S.; Banerjee, P.; Franco, A. Hydrothermal synthesis of nickel doped cobalt ferrite nanoparticles: Optical and magnetic properties. J. Mater. Sci.-Mater. Electron. 2018, 29, 14657-14667. [CrossRef]

12. Bochmann, S.; Döhler, D.; Trapp, B.; Stano, M.; Fruchart, O.; Bachmann, J. Preparation and physical properties of soft magnetic nickel-cobalt three-segmented nanowires. J. Appl. Phys. 2018, 124, 163907. [CrossRef]

13. Gracheva, I.E.; Olchowik, G.; Gareev, K.G.; Moshnikov, V.A.; Kuznetsov, V.V.; Olchowik, J.M. Investigations of nanocomposite magnetic materials based on the oxides of iron, nickel, cobalt and silicon dioxide. J. Phys. Chem. Solids 2013, 74, 656-663. [CrossRef]

14. Mehrnaz, G. Synthesis of magnetic nanoparticles of cobalt and nickel modified iron oxides by thermal decomposition of metal-carbonyl for biomedical and biochemical applications. Clin. Biochem. 2011, 44, S213. [CrossRef]

15. Babes, L.; Denizot, B.; Tanguy, G.; Le, J.J.; Jallet, P. Synthesis of iron oxide nanoparticles used as MRI contrast agents: A parametric study. J. Colloid Interface Sci. 1999, 212, 474-482. [CrossRef] [PubMed]

16. Mahdieh, A.; Mahdavian, A.R.; Salehimobarakeh, H. Chemical modification of magnetite nanoparticles and preparation of acrylic-base magnetic nanocomposite particles via miniemulsion polymerization. J. Magn. Magn. Mater. 2017, 426, 230-238. [CrossRef]

17. Pineda, M.G.; Torres, S.; López, L.V.; Enríquez-Medrano, F.J.; de León, R.D.; Fernández, S.; Saade, H.; López, R.G. Chitosan-coated magnetic nanoparticles prepared in one-step by precipitation in a high-aqueous phase content reverse microemulsion. Molecules 2014, 19, 9273-9287. [CrossRef]

18. Cótica, L.F.; Freitas, V.F.; Dias, G.S.; Santos, I.A.; Vendrame, S.C.; Khalil, N.M.; Mainardes, R.M.; Staruch, M.; Jain, M. Simple and facile approach to synthesize magnetite nanoparticles and assessment of their effects on blood cells. J. Magn. Magn. Mater. 2012, 324, 559-563. [CrossRef]

19. Yang, Z.; Wang, S.; Xie, K.; Dai, Y.; Ma, W. Versatile functionalization of $\mathrm{Fe}_{3} \mathrm{O}_{4}$ nanoparticles via RAFT polymerization and click chemistry. Appl. Surf. Sci. 2011, 257, 10384-10389.

20. Howdyshell, M.L.; Prikockis, M.; Lauback, S.; Vieira, G.B. Deterministic and stochastic trajectories of magnetic particles: Mapping energy landscapes for technology and biology. IEEE Trans. Magn. 2014, 50, 1-7. [CrossRef]

21. Suwa, M.; Watarai, H. Magnetoanalysis of micro/nanoparticles: A review. Anal. Chim. Acta 2011, 690, 137-147. [CrossRef] [PubMed]

22. Mohajershojaei, K.; Mahmoodi, N.M.; Khosravi, A. Immobilization of laccase enzyme onto titania nanoparticle and decolorization of dyes from single and binary systems. Biotechnol. Bioprocess Eng. 2015, 20, 109-116. [CrossRef]

23. Ma, Y.X.; Li, Y.F.; Zhao, G.H.; Yang, L.Q.; Wang, J.Z.; Shan, X.; Yan, X. Preparation and characterization of graphite nanosheets decorated with $\mathrm{Fe}_{3} \mathrm{O}_{4}$ nanoparticles used in the immobilization of glucoamylase. Carbon 2012, 50, 2976-2986. [CrossRef]

24. Thünemann, A.F.; Rolf, S.; Knappe, P.; Weidner, S. In situ analysis of a bimodal size distribution of superparamagnetic nanoparticles. Anal. Chem. 2009, 81, 296-301. [CrossRef]

25. Xu, J.; Sun, J.; Wang, Y.; Sheng, J.; Wang, F.; Sun, M. Application of iron magnetic nanoparticles in protein immobilization. Molecules 2014, 19, 11465-11486. [CrossRef] [PubMed]

26. Soozanipour, A.; Taheri-Kafrani, A.; Isfahani, A.L. Covalent attachment of xylanase on functionalized magnetic nanoparticles and determination of its activity and stability. Chem. Eng. J. 2015, 270, 235-243. [CrossRef] 
27. Yi-Tak, L.; Destefano, J.J. A primer-free method that selects high-affinity single-stranded DNA aptamers using thermostable RNA ligase. Anal. Biochem. 2011, 414, 246-253.

28. Luzi, E.; Minunni, M.; Tombelli, S.; Mascini, M. New trends in affinity sensing: Aptamers for ligand binding. TrAC-Trend. Anal. Chem. 2003, 22, 810-818. [CrossRef]

29. Ozalp, V.C.; Kavruk, M.; Dilek, O.; Bayrac, A.T. Aptamers: Molecular tools for medical diagnosis. Curr. Top. Med. Chem. 2015, 15, 1125-1137. [CrossRef]

30. Xi, Z.; Huang, R.; Deng, Y.; He, N. Progress in selection and biomedical applications of aptamers. J. Biomed. Nanotechnol. 2014, 10, 3043-3062. [CrossRef]

31. Tuerk, C.; Gold, L. Systematic evolution of ligands by exponential enrichment: RNA ligands to bacteriophage T4 DNA polymerase. Science 1990, 249, 505-510. [CrossRef] [PubMed]

32. Cho, E.J.; Lee, J.W.; Ellington, A.D. Applications of aptamers as sensors. Annu. Rev. Anal. Chem. 2009, 2, 241-264. [CrossRef]

33. Han, B.; Zhao, C.; Yin, J.; Wang, H. High performance aptamer affinity chromatography for single-step selective extraction and screening of basic protein lysozyme. J. Chromatogr. B 2012, 903, 112-117. [CrossRef] [PubMed]

34. Bayramoglu, G.; Ozalp, V.C.; Yilmaz, M.; Guler, U.; Salih, B.; Arica, M.Y. Lysozyme specific aptamer immobilized MCM-41 silicate for single-step purification and quartz crystal microbalance (QCM)-based determination of lysozyme from chicken egg white. Microporous Mesoporous Mater. 2015, 207, 95-104. [CrossRef]

35. Yang, T.Z.; Shen, C.M.; Li, Z.A.; Zhang, H.Z.; Xiao, C.W.; Chen, S.T.; Xu, Z.C.; Shi, D.X.; Li, J.Q.; Gao, H.J. Highly ordered self-assembly with large area of $\mathrm{Fe}_{3} \mathrm{O}_{4}$ nanoparticles and the magnetic properties. J. Phys. Chem. B 2005, 109, 23233-23236. [CrossRef]

36. Dan, H.; Dong, X.; Lu, X.; Ding, Y. Facile route to synthesize mesoporous SBA-15 rods with different sizes for lysozyme immobilization. J. Sol-Gel Sci. Technol. 2016, 3, 782-790. [CrossRef]

37. Altıntaş, E.B.; Tüzmen, N.; Candan, N.; Denizli, A. Use of magnetic poly(glycidyl methacrylate) monosize beads for the purification of lysozyme in batch system. J. Chromatogr. B Anal. Technol. Biomed. Life Sci. 2007, 853, 105-113. [CrossRef] [PubMed]

38. Başar, N.; Uzun, L.; Güner, A.; Denizli, A. Lysozyme purification with dye-affinity beads under magnetic field. Int. J. Biol. Macromol. 2007, 41, 234-242. [CrossRef]

39. Chen, X.; Liu, J.; Feng, Z.; Shao, Z. Macroporous chitosan/carboxymethylcellulose blend membranes and their application for lysozyme adsorption. J. Appl. Polym. Sci. 2010, 96, 1267-1274. [CrossRef]

40. Sun, J.; Wu, L.; Chen, J. Efficient lysozyme adsorption on chitosan/hydroxyapatite hybrid membrane via in situ synthesis. Cellu 2016, 23, 3861-3874. [CrossRef]

41. Karpovich, D.S.; Blanchard, G.J. Direct Measurement of the Adsorption Kinetics of Alkanethiolate Self-Assembled Monolayers on a Microcrystalline Gold Surface. Langmuir 1994, 10, 3315-3322. [CrossRef]

42. Areco, M.M.; Afonso, M.D.S. Copper, zinc, cadmium and lead biosorption by gymnogongrus torulosus. thermodynamics and kinetics studies. Colloids Surf. B 2010, 81, 620-628. [CrossRef] [PubMed]

43. Mehmet, O.; Say, R.; Denizli, A. Molecular imprinted particles for lysozyme purification. Mater. Sci. Eng. C 2007, 27, 90-99.

44. Donat, R.; Akdogan, A.; Erdem, E.; Cetisli, H. Thermodynamics of $\mathrm{Pb}^{2+}$ and $\mathrm{Ni}^{2+}$ adsorption onto natural bentonite from aqueous solutions. J. Colloid Interface Sci. 2005, 286, 43-52. [CrossRef] [PubMed]

(C) 2019 by the authors. Licensee MDPI, Basel, Switzerland. This article is an open access article distributed under the terms and conditions of the Creative Commons Attribution (CC BY) license (http:/ / creativecommons.org/licenses/by/4.0/). 